\title{
Analysing the activity of work in emergency incident management
}

Analyse de l'activité de travail dans la gestion des situations d'urgence

\section{Christine Owen}

\section{(2) OpenEdition \\ Journals}

Electronic version

URL: http://journals.openedition.org/activites/1512

DOI: 10.4000/activites.1512

ISSN: $1765-2723$

\section{Publisher}

ARPACT - Association Recherches et Pratiques sur les ACTivités

\section{Electronic reference}

Christine Owen, "Analysing the activity of work in emergency incident management ", Activités [Online], 4-1 | avril 2007, Online since 15 April 2007, connection on 21 April 2019. URL : http:// journals.openedition.org/activites/1512 ; DOI : 10.4000/activites.1512

\section{(9) $\odot \Theta \Theta$}

Activités est mis à disposition selon les termes de la licence Creative Commons Attribution - Pas d'Utilisation Commerciale - Pas de Modification 4.0 International. 


\title{
Analysing the activity of work in emergency incident management
}

\author{
C.A. Owen \\ Bushfire Co-operative Research Centre \\ University of Tasmania, Private Bag 66, Hobart, 7001, Tasmania, Australia
}

\begin{abstract}
The paper addresses the call by Rasmussen and Svedung (2000) for (i) more research into emergency incident management and (ii) more attention to be given to the nature of emergency-as-activity, rather than the current preoccupation on organisational structures. Drawing on French-speaking and Nordic approaches to activity, this paper proposes a taxonomy of work activity focussed on emergency-as-activity. The taxonomy draws on concepts found in ergonomic research into other HRO domains and empirical analysis conducted in a related HRO environment (air traffic control). The paper constructs a set of propositions that will be empirically tested in a study investigating work activity in multi-agency emergency incident management for bushfires in Australia. The taxonomy based on related HRO environments emphasising communicative practices, proposes that the most salient features of work activity in managing incidents will be their spatio-temporal features, their complexity and the need to act interdependently with others.
\end{abstract}

KEYWORDS:

activity theory, emergency incident management, coping with complexity

\section{1.- Introduction}

One of the most compelling problems facing ergonomic communities is how to design to manage and mitigate events that occur irregularly, but that when needed, require multiple forms of coordination and innovation within short and temporary time-spans in contexts of uncertainty and that have significant consequences. Emergency Incident Management includes these features and is an area that has been under theorized, despite its critical importance to the well-being of society. This paper picks up the call by Rasmussen and Svedung (2000) to identify alternative ways of thinking about information flow and organizing in emergencies.

This is important because one of the often cited criticisms of disasters that are not managed well is that they failed to have strong information gathering, communication and coordination mechanisms in place and did not make use of these kinds of resources.

In Australia and elsewhere, there has been much attention given to developing appropriate coordination and decision-making structures appropriées (Bigley, \& Roberts, 2001; Australasian Fire Authorities Council, 2005). However, as Rasmussen and Svedung (2000) note, the preoccupation with structures of organizing is not enough. Attention is also needed on what kinds of practices will support 'shared mindfulness' (Shawn Burke, Wilson, \& Salas, 2005) and the development of processes supporting high-reliability practices (Shawn Burke et al., 2005). This paper attempts to make a contribution to this field by drawing on an analysis of how work activity is experienced by operators involved in a related example of high-reliability work to identity a set of propositions that can be investigated to better understand how shared mindfulness and coordinated information flow can be enhanced in emergency incident management.

Two key questions underpinning the paper are: what might the ergonomic research literature have to 
add to the understanding of emergency management activities? And: what might activity-theoretical analyses of emergency management work have to offer to ergonomists interested in design of complex and uncertain systems?

\section{2.- Activity theoretical approaches}

It is beyond the scope of this paper to go into detail about the assumptions underpinning the activitytheoretical approaches employed here. For further elaboration see (Engestrom, 2000; Engestrom, Puonti, \& Seppänen, 2003; Daniellou, 2005). Both approaches emphasise the means by which activity is mediated by tools and other cultural artefacts.

\section{1.-French-speaking approaches to activity}

The concept of activity in French-speaking literature has been excellently synthesised by Daniellou (2005). Two key ideas are employed here. One of the key features in French-speaking approaches to activity is attention to how work really occurs in contrast to how it is prescribed. In this literature attention is given to producing fine-grained understandings of real work activity. A second key feature is that of a focus on the collective. What is important in this focus is identifying the collective as a unit of analysis. Other useful ideas include auto-confrontation. That is, engaging the practitioner in developing an explanation, particularly of why 'real-work' differs from that of 'prescribed-work' in order to understand the difficulties workers encounter in their activity and of the adjustments needed to deal with variability. Within all of these ideas is an underpinning epistemological intention of emphasising the subjective construction of activity from the workers point of view.

\section{2.-Nordic approaches to activity}

The Nordic approaches found in the writings of Engestrom and colleagues (Engestrom, 2000; Engestrom et al., 2003) share some features with their French-speaking counterparts and many differences, though it is not possible to discuss these here. From Nordic approaches to activity however the notion of tension and contradiction is important and inherent in all activity systems. For Engestrom highlighting these systemic tensions provides useful insights into drivers for organisational development and change. In Nordic approaches to activity the processes through which activity is structured (e.g., the implicit and explicit rules used, how the division of labour is organised etc) are important features that provide opportunities and constraints on workers that workers may or may not be conscious of. The historical trajectory of work is also considered important.

\section{3.- Background empirical analysis of the taxonomy}

This paper draws on an analysis of work activity undertaken in another high-reliability environment, that of air traffic control to develop a set of propositions for further investigation in emergency incident management. In that previous study described elsewhere (Owen, 1999; 2001) 100 interviews were undertaken with air traffic controllers in a variety of positions and 30 hours of fine-grained observation using a practice similar to that of auto-confrontation were employed to develop an account of the work activity under scrutiny.

\section{4.- Proposed dimensions of emergency incident management work activity}

As a result of the empirical work described above, and drawing on ergonomic research into related 
domains, three dimensions to work activity involved in emergency incident management are proposed. It is proposed that workers involved in emergency incident management will subjectively experience their activity in terms of its temporalilty, degree of complexity and degree of interdependency.

First, emergency incident management will be temporally demanding because it occurs in a dynamic "real time" environment, cannot be stopped but must be responded to often in periods of intensity.

Second, emergency incident management work will be experienced complexly. Complex work requires the coordination of multiple tasks that in turn require higher order thinking and - in combination with the temporality of work - an awareness and understanding is needed of the various permutations of problems and solutions that successful task completion may require within a limited period of time. Moreover, by definition, the knowledge base for any emergency will be inherently imperfect. The possible consequences of some of the actions involved in the work will be quite taxing for the workers involved.

Finally there will be a degree of interdependency involved in operators managing various aspects of the emergency. Depending on the complexity of the emergency involved this may mean that workers need to draw on multiple resources and negotiate plans and actions with a number of others, who may represent different agencies with related interests.

The interdependency and complexity of the work involved is addressed by the structure of an incident management system [for an excellent discussion of this structure see Bigley and Roberts (2001)]. Within the structure there is an ordering of processes for managing interdependency. However, as yet no fine-grained understanding has been developed from the workers point of view. These three dimensions and their proposed attributes are outlined in Table 1.

\begin{tabular}{|l|l|}
\hline Dimension & Definition \\
\hline Temporal & $\begin{array}{l}\text { The rhythm, pattern and speed at which events are occurring (e.g., } \\
\text { fast, slow). }\end{array}$ \\
\hline Tempo & The transition between changes in tempo of the event or aspects \\
\hline Escalation & $\begin{array}{l}\text { Synchronicity between actions \& requirements needed in the incident } \\
\text { management system when the tempo escalates }\end{array}$ \\
\hline Responsiveness & $\begin{array}{l}\text { Problem-based event trajectories that emerge and permutate through } \\
\text { time }\end{array}$ \\
\hline Complexity & $\begin{array}{l}\text { Multiple disturbances leading to anticipated and unanticipated } \\
\text { consequences }\end{array}$ \\
\hline Cascading & $\begin{array}{l}\text { Multiple tasks to be undertaken and resolved that set up competing } \\
\text { goals }\end{array}$ \\
\hline $\begin{array}{l}\text { Multiplicity and goal } \\
\text { conflicts }\end{array}$ & $\begin{array}{l}\text { The functional interconnections between the incident management } \\
\text { system parts requiring coordination }\end{array}$ \\
\hline Interdependence & $\begin{array}{l}\text { Conflict arising from different intentions between workers and/or } \\
\text { between workers and systems }\end{array}$ \\
\hline Coupling & $\begin{array}{l}\text { The process where more than one activity must happen at the same } \\
\text { time }\end{array}$ \\
\hline $\begin{array}{l}\text { Interdependent goal } \\
\text { conflicts }\end{array}$ & When the output of one activity is required by the next worker \\
\hline Simultaneity &
\end{tabular}

Table 1: Proposed taxonomy of dimensions of emergency work.

\section{1.- The temporal dimension of emergency incident management}

One of the scarcest resources available of an emergency is often that of time. In part, this is because once commenced, events must be managed as and when they occur and the amount of time and de- 
velopment of events will be uncertain.

\subsection{1.- Tempo and escalation}

Frequently in an emergency the tempo (see Table 1) can change and escalate and those involved need to be able to detect this. A key question for ergonomists working in this field is how can decisionsupport systems be developed to visibilise changes in tempo, such that early detection of escalation (see Table 1) can result in early responsiveness (see Table 1)? Such systems need to be able to track resources to ensure that they have been appropriately responsive and have not lagged in their deployment. Sometimes an emergency can escalate because an incident controller can think a resource has been deployed as a response only to find out later that this has not occurred. Temporal lags in responsiveness are created by humans and technological resources.

The incident controller needs early advice if an escalation is occurring in order to be able to "shift gears" to keep up with the event. Failing to do so means that unanticipated consequences are more likely. This tension in work practice (i.e., failing to keep up with the escalation of the work tempo) has been described in other ergonomic work process studies as when the operator "falls behind the plane" (Woods, \& Cook, 1999, p. 154). That is, the work processes get ahead of the operator who then struggles to catch up and get in front of the temporal event in order to be proactive.

\subsection{2.- Temporal responsiveness}

In terms of tensions and difficulties experienced by the incident controller, it is proposed that the intensity of work created by the demands involved with processing and coordinating information within a limited time frame sets up a fertile ground for an emergency event to compound. It is also proposed that failures to monitor the level of escalation in tempo will create increased pressure; especially if the time it takes to notice an escalation means that options that were available at a slower pace are no longer available. It is also proposed that human and technological lags in responsiveness will increase vulnerability in systems.

\section{2.-The complexity dimension of emergency incident management}

Emergency incident management is demanding for a range of reasons, one of which is that it will involve higher-order thinking and decision-making (McLennan, Omodei, Holgate, \& Wearing, 2005).

However, it is also demanding because of the possibility of the seriousness of the consequences should it go wrong. The consequences of a poor decision may result in exacerbating an existing threat to the environment and to the health or lives of people either working in the organization or affected by it (McCarthy, Healy, Wright, \& Harrison, 1997).

In the taxonomy four attributes have been identified from the literature and that are proposed would need to be successfully managed when working in emergency environments. These are problem demands; emergent variability; cascading, and multiplicity and goal conflicts (see Table One).

\subsection{1.- Problem demands}

When work involves higher order thinking in a context of potential significant consequence the demands felt by emergency incident controllers may be considerable. To operate in a high-reliability environment where the consequences of action may put lives at risk, operators need to both be aware of the danger but not dwell on it. This requires a constant sense of awareness and vigilance on the part of the operator and a pre-occupation with the potential for failure (Rochlin, 1999). 


\subsection{2.- Emergent variability:}

Another feature of work in emergency incident management will be its variability. "Trouble" may be "routine" (Suchman, 1996) when, for example, a bushfire follows an anticipated trajectory and the outcome follows a known pattern which can be mitigated and managed. However, sometimes unanticipated trouble will emerge and other problems will need to be solved. The concept of 'shared mindfulness' is often used in the ergonomics literature as a resource that can assist in overcoming problems associated with emergent variability. "Mindfulness is less about decision making, a traditional focus of organization theory and accident prevention, and more about inquiry and interpretation grounded in capabilities for action" (Weick, Sutcliffe, \& Obstfield, 1999).

Another resource found in the ergonomics literature that is useful here is the concept of individual and shared mental models about the problem situation. For Mathieu, Goodwin, Heffner, Salas and Cannon-Bowers (2000), a mental model is a mechanism whereby humans generate descriptions of a system's purpose and form as well as explanations of system functioning and observed systems states and predictions of future system. Mathieu et al. (2000) contend that there can be multiple mental models coexisting among team members at any given point in time and that these would include models of job role, task and technology. The concept of situation awareness is also useful here [see Endsley (2000)], although in the French-speaking literature this has been criticised because the representation is always regarded as an external one [for example Hoc (2001)].

That individuals working interdependently can hold different types of knowledge and mental models about an emergency can be both a constraint and a resource. That is, if different levels of experience and knowledge about the emergency are collectively brought to bear such that a coherent understanding of the problem and possible solutions are reached, then those different knowledges will be a resource. If on the other hand, different knowledge and experiences are shared but fail to add to a coherent account or to possible solutions then these differences simply add to the vulnerability of the situation. All problems have trajectories that can be exacerbated if things go wrong.

\subsection{3.- Cascading}

The intersection between the temporal flow of work and its complexity occurs through emergent variability. In this sense, the notion of variability links with the temporal notion of escalation. When complexity is cascading (i.e. when there are multiple disturbances leading to unanticipated consequences) these problem demands will be exacerbated by the temporal demands associated with escalation.

To successfully deal with emergent variability requires both appropriate situation awareness about the emergency as well as resilience and containment (Duffy, 1993). Operators will need to "deal with what is in front of them through operations that have an emergent quality similar to the activity of bricolage" (Weick, 2001). The French word bricolage (which has no precise equivalent in English) means to use whatever resources and repertoire are at hand to perform whatever task one faces. Invariably the resources are less well suited to the exact project than one would prefer but they are all there is.

It is proposed that operators involved in emergency incident management will use individual resources of constantly checking and scanning the features of the emergency to notice unanticipated disturbances and act on them before they cascade. It is also proposed that this will involve having both temporal and cognitive awareness of the situation. Under these circumstances there will be a pre-occupation with the potential for variability to lead to failure. In describing other High-3 environments, Rochlin (1999) called this "working with a continuous expectation of surprise".

\subsection{4.- Task multiplicity and goal conflicts.}

It is argued that multiplicity of goals and conflicts are always present in work situations. This can 
occur as an individual operator attempts to resolve his or her work problems alone or in relation others.

From the activity theoretical literature it is proposed that in emergency incident management there will be tensions in the way competing demands are prescribed to be resolved (through a division of labour) and the way they really occur in performing the activity. It is proposed that the successful prioritization and management of competing demands will depend on the level of shared understanding of the situation and cross-training (Mathieu et al, 2000). From the Nordic activity theoretical perspective, it is also proposed that goal conflicts will be embedded in the arrangement of the tasks, the application of rules and by the division of labour inherent in the Emergency Incident Control structure established to address the event. Multiple competing goals occur not just for individuals as they undertake their work, but especially as they engage in that work in relation to others.

\section{3.- The interdependent nature of emergency incident management.}

When work is complex and occurs within a real-time temporal domain, multiple actors are almost invariably involved. This is because the task is so complex that no one single individual is capable of undertaking the entire job (Lave, 1996) and in so doing a successful work outcome is contingent on other operators performing their work within another part of the system (Bardram, 2000). Three attributes (see Table One) are important in considering the interdependent nature of emergency incident management.

\subsection{1.- Coupling}

Coupling refers to the functional interconnections between parts of a system. Interdependent actions are either loosely or tightly coupled (Woods, \& Cook, 1999). In interdependent and complex systems, coupling of tasks can occur directly between operators or may be mediated through technological tools and artefacts. When High-3 environments are tightly coupled (Perrow, 1999), there is a strong relationship of dependence between two activities and little room for uncoordinated action.

\subsection{2.- Interdependent goal conflicts.}

When individual operators are solving complex problems and managing multiple tasks in an emergency they have to prioritise those tasks and their possible outcomes. Often this process involves comparing one potential outcome with another and then coordinating that outcome with others. Interdependence and complexity intersect when workers are involved in managing multiple competing goals resulting in negotiated talk and trade-offs. In terms of the division of labour in emergency incident management, it is proposed that two aspects will be important in coordination: simultaneity and the sequencing of activity Bardram (2000).

\subsection{3.- Simultaneity and sequencing.}

Interdependent simultaneity is a term Bardram (2000) uses to describe the process where more than one activity must happen at the same time between operators. Interdependent sequencing refers to when the output of one activity is required by the next Bardram (2000). These activities clearly have implications for the timeliness of the temporal flow of the work discussed earlier.

It is proposed that interdependent work activity will intersect with complexity especially when unanticipated disturbances (cascading) occurs. 


\section{5.- Conclusion}

This paper has attempted to establish a contribution to addressing Rasmussen and Svedung's (2000) call for more research into work activity in the management of emergencies by proposing a focus on the nature of the work activity and implications for information flow.

The paper has identified a number of concepts found in the ergonomic research literature that promise to make a useful contribution to the understanding of emergency management activities. In doing so a taxonomy for thinking about work activity in emergency incident management has been proposed.

The paper also set out to initiate discussion on what might activity-theoretical analyses of emergency management work have to offer to ergonomists interested in design of complex and uncertain systems. The following questions emerge from this analysis and are likely to be of interest to ergonomic researchers interested in this domain:

- How is the observed work activity of emergency incident management different from that which is prescribed?

- What possible tensions and contradictions will be inherent in the work structure, with particular reference to the intersection of rules, division of labour and object of activity?

- How do emergency incident management controllers explain the differences observed and how these tensions are worked through?

- In what ways are tensions, contradictions and difficulties worked through connected to the features of how the work may be experienced by the operator in terms of the dimensions of temporality, complexity and interdependence?

- To what extent do the dimensions described here account for work activity in emergency incident management and what other dimensions are salient?

- How might operators desire the identified dimensions of work activity to be mediated by ergonomic intervention?

- To what degree can ergonomic interventions facilitate the management of the work activity?

The paper has established a framework and a series of proposals for further investigation in an empirical study planned in collaboration with Bushfire Management agencies in Australia.

\section{REFERENCING}

Owen, C. (2007). Analysing the activity of work in emergency incident management @ctivités, 4 (1), pp. 217-225, http://www.activites.org/v4n1/v4n1.pdf.

\section{REFERENCES}

Australasian Fire Authorities Council (AFAC) (2005). The Australasian inter-service incident management system. (3 edition). Melbourne: Australasian Fire Authorities Council.

Bardram, J. (2000). Temporal coordination. Computer Supported Cooperative Work, 9, 157-187.

Bigley, G., \& Roberts, K. (2001). The incident command system: high reliability organizing for complex and volatile task environments. Academy of Management Journal, 44(6), 1281-1299.

Daniellou, F. (2005). The French-speaking ergonomist. approach to work activity: cross-influences of field intervention and conceptual models. Theoretical Issues in Ergonomics Science, 6(5), 409-427.

Duffy, L. (1993). Team. In J. Castellan (Ed.), Individual and group decision making: Current issues (pp. 247266)., Hillsdale, New Jersey: Lawrence Erlbaum.

Endsley, M. (2000). Direct measurement of situation awareness: Validity and use of SAGAT. In M. Endsley 
\& D. Garland (Eds.), Situation awareness analysis and measurement (pp. 147-173). London: Lawrence Erlbaum Associates.

Engestrom Y. (2000). Activity theory as a framework for analysing and redesigning work. Ergonomics, 43(7), 960-974.

Engestrom, Y. Puonti, A., \& Seppänen, L. (2003). Spatial and temporal expansion of the object as a challenge for reorganizing work. In D. Nicolini, S. Gherardi, \& D. Yanow (Eds.), Knowing in Organizations: A Practice-based Approach (pp. 151-186). Armonk: M. E. Sharpe.

Hoc, J.-M. (2001). Towards a cognitive approach to human-machine cooperation in dynamic situations. International Journal of Human-Computer Studies, 54(4), 509-540.

Lave, J. (1996). In S. Chaiklin, \& J. Lave (Eds), Understanding practice: Perspectives on activity and context. New York: Cambridge University Press.

Mathieu, J. Goodwin, G. Hefner, T. Salas, E., \& Cannon-Bowers, J. (2000). The influence of shared mental models on team process and performance. Journal of Applied Psychology, 85(2), 273-283.

McCarthy, J. Healy, G. Wright, P., \& Harrison, M. (1997). Accountability of work activity in highconsequence work systems: Human error in context. International Journal Human-Computer Studies, 47, 735-766.

McLennan, J. Omodei, M. Holgate, A., \& Wearing, A. (2005). Decision making effectiveness in wildfire incident management teams. In J. Schraagen (Ed.), Proceedings of the seventh International NDM Conference, Amsterdam, Netherlands, June.

Owen, C. (1999). Learning in the workplace: The case of air traffic control. Unpublished PhD Dissertation, University of Tasmania, Hobart.

Owen, C. (2001). The role of organisational context in mediating workplace learning and performance. Computers in Human Behaviour, 17 (5/6), 597-614.

Perrow, C. (1999). Normal accidents: Living with high risk technologies. New York: Basic Books.

Rasmussen, J., \& Svedung, I. (2000). Proactive risk management in a dynamic society. Swedish Rescue Services Agency, Karlstad, Sweden.

Rochlin, G. (1999). Safe operation as a social construct. Ergonomics, 42(11), 1549-1560.

Shawn Burke, C. Wilson, K., \& Salas, E. (2005). The use of a teambased strategy for organizational transformation: guidance for moving toward a high reliability organization. Theoretical Issues in Ergonomics Science, 6(6), 509-530.

Suchman, L. (1996). Constituting shared workplaces Constituting shared workplaces. In Y. Engestrom, \& D. Middleton (Eds.), Cognition and communication at work (pp. 35-60). New York: Cambridge University Press.

Weick, K. (2001). Making sense of the organization. Blackwell Publishers Inc. Massachusetts.

Weick, K. Sutcliffe, K., \& Obstfield, D. (Eds.) (1999). Organizing for high reliability: Processes of collective mindfulness. Connecticut: Research in Organizational Behavior, JAI Press Inc.

Woods, D., \& Cook, R. (1999). Perspective on human error: Hindsight bias and local rationality. In F. Durso (Ed.), Handbook of applied cognition (pp. 141-171). New York: John Wiley \& Sons.

\section{RÉSUMÉ}

Cet article répond à la demande formulée par Rasmussen et Svedung (2000) pour que plus de recherches soient réalisées au sujet de la gestion des situations d'urgence (i) et pour que l'attention se porte sur la situation d'urgence vue en tant qu'activité (ii), plutôt que sur les préoccupations courantes concernant les structures d'organisation. Se basant sur les 
approches francophones et nordiques de l'activité, cet article propose une taxonomie de l'activité de travail centrée sur la situation-d'urgenceconsidérée-comme-une activité. Cette taxonomie se base sur des concepts issus de la recherche en ergonomie menée dans divers types d'organisations de haute fiabilité (HRO), et sur des analyses empiriques conduites dans un de ces environnements (celui de la surveillance du trafic aérien). Notre document construit un ensemble de propositions qui seront ensuite vérifiées de manière empirique par le biais d'une étude portant sur l'analyse de l'activité de travail lors de la gestion multifactorielle de situations d'urgence concernant les feux de brousse en Australie. La taxonomie, basée sur des environnements liés aux organisations de haute fiabilité mettant l'accent sur les pratiques communicatives, propose que les caractéristiques les plus saillantes de l'activité de travail relative à la gestion des incidents soient leurs caractéristiques spatio-temporelles, leur complexité, et leur interdépendance.

MOTS-CLÉS

Théorie de l'activité, gestion des situations d'urgence, faire face à la complexité

\section{RESUMEN}

Este artículo responde a la invitación de Rasmussen y Svedung (2000) que proponen ir más allá del clásico estudio de las estructuras organizativas (i) realizando más investigación sobre la gestión de los incidentes en emergencias y (ii) prestándole mayor atención a la naturaleza misma de la emergencia, en tanto actividad. Utilizando los enfoques franco-parlante y nórdico de la actividad, este artículo propone una taxonomía de la actividad de trabajo centrada en la emergencia entendida como actividad. La taxonomía recurre a conceptos de la investigación en ergonomía en otros terrenos de investigación de la HRO y a análisis empíricos realizados en ambientes relacionados con las HRO (control de tránsito aéreo). El artículo presenta una serie de propuestas que serán evaluadas empíricamente en un segundo estudio. Este investigará la actividad de gestión de incidentes de emergencia por parte de un conjunto de organizaciones en los incendios de monte en Australia. La taxonomía, basada en situaciones de HRO semejantes en las que se rescatan sobre todo las prácticas de comunicación, propone que los rasgos más salientes de actividad de trabajo en la gestión de incidentes son sus rasgos espacio-temporales, su complejidad y la necesidad de actuar en forma interdependiente con los colegas.

\section{PALABRAS-ClAVE}

Teoría de la actividad, gestión de incidentes de emergencias, afrontamiento de la complejidad 